\title{
ИМIIЕРАМОРСКАЯ
}

\section{АРХЕОЛОГИЧЕСКАЯ КОМИССИЯ}

\section{(1859-1917)}

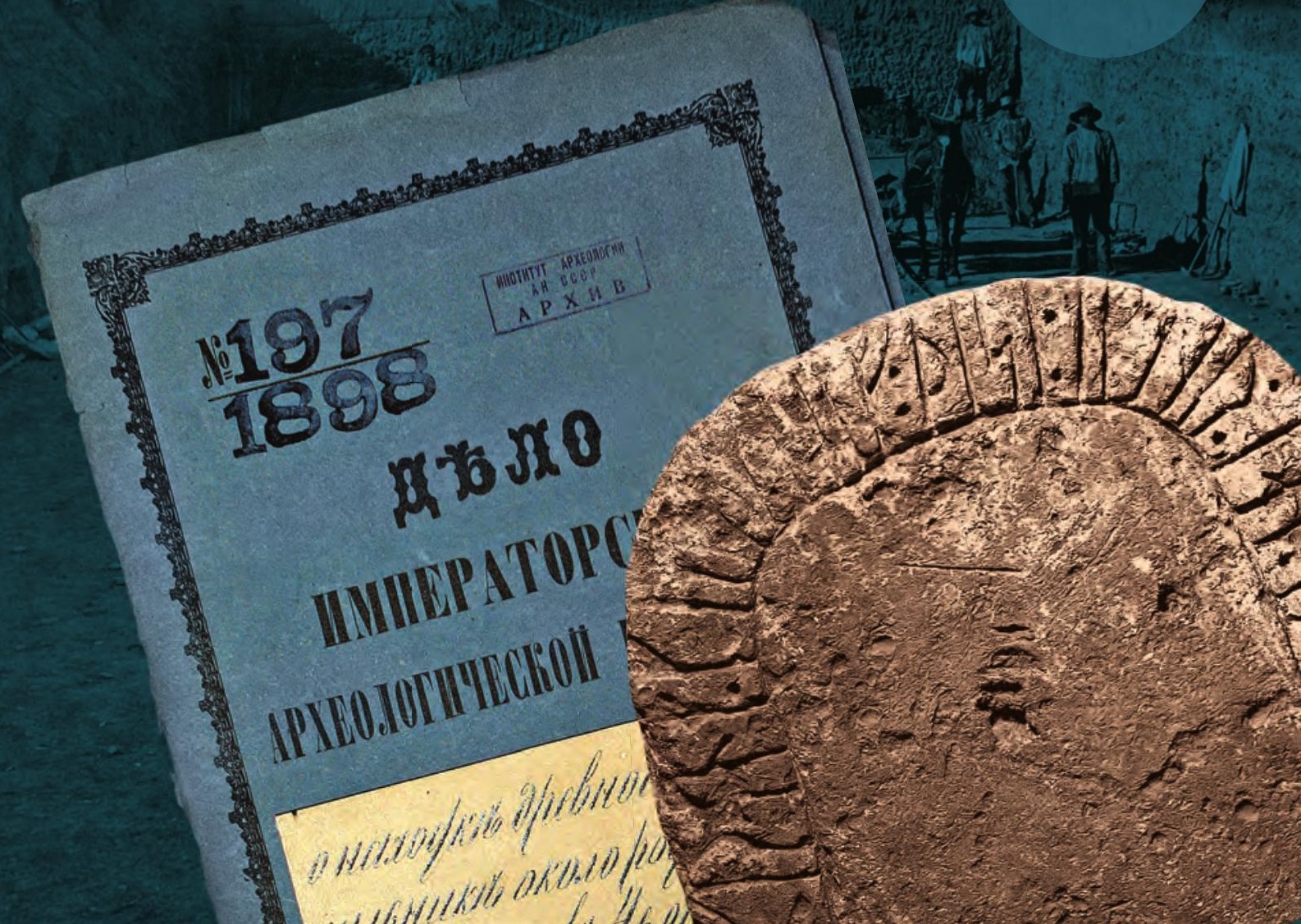


Всем потрудившимся на ниве отечественной археологии ПОСВЯЩАЕТСЯ 


\section{THE IMPERIAL ARCHAEOLOGICAL COMMISSION \\ (1859-1917)}

\section{HISTORY OF THE FIRST STATE INSTITUTION OF RUSSIAN ARCHAEOLOGY \\ FROM THE BEGINNING UNTIL THE REFORM}

\section{Volume 1}

Edited by

Alexander Musin \& Maria Medvedeva

$2^{\text {nd }}$ revised edition 


\section{ИМПЕРАТОРСКАЯ АРХЕО.ЛОГИЧЕСКАЯ КОМИССИЯ}

\section{(1859-1917)}

\section{ИСТОРИЯ ПЕРВОГО ГОСУДАРСТВЕННОГО УЧРЕЖДЕНИЯ РОССИЙСКОЙ АРХЕОЛОГИИ ОТ ОСНОВАНИЯ ДО РЕФОРМЫ}

\section{Tом 1}

Научные редакторы-составители

А.Е. Мусин и М.В. Медведева

2-е издание, переработанное и дополненное 
Исследование осуществлено при финансовой поддержке Российского гуманитарного научного фонда (проект № $07-01-512 \mathrm{a})$

Первое издание осуществлено при финансовой поддержке Российского гуманитарного научного фонда (проект № 09-01-16101д)

И54 Императорская археологическая комиссия (1859-1917) : история первого государственного учреждения российской археологии от основания до реформы : Коллективная монография : в 2 т. Т. 1 / науч. ред.-сост. А.Е. Мусин, М.В. Медведева. 2-е изд., перераб. и доп. - СПб. : ИИМК РАН, 2019. - 888 (1616) с.

\section{ISBN 978-5-9072-9806-4}

DOI 10.31600/978-5-9072-9806-4

Книга посвящена истории Императорской археологической комиссии, первого государственного археологического учреждения в России. Комиссия сыграла важную роль в становлении российской археологии как науки, в сложении теории и практики реставрации объектов культурного наследия и формировании мер по охране памятников культуры в России XIX - начала XX в. В книге впервые систематически изложена и охарактеризована разносторонняя деятельность ИАК, даны биографии членов и сотрудников Комиссии, опубликован справочный материал по ее исследовательской деятельности. В богато иллюстрированном издании использованы уникальные фотографии из Научного архива ИИМК РАН. Второе издание коллективного труда, переработанное и дополненное, предназначено специалистам в области отечественной археологии и истории, историкам искусства и реставраторам, общественным и политическим деятелям, сотрудникам органов охраны памятников, студентам исторических специальностей, всем, интересующимся судьбой памятников культуры.

Рецензенты:

чл.-корр. РАН И.В. Тункина, к.и.н. О.А. Сиротина

Редакционная коллегия:

к.и.н. О.И. Богуславский, д.и.н. В.А. Лапшин (председатель), к.и.н. М.В. Медведева (науч. ред.-сост.), д.и.н. А.Е. Мусин (науч. ред.-сост.), д.и.н. Н.И. Платонова

Предисловие - д.и.н. В. А. Лапшин; Предисловие к первому изданию - чл.-корр. РАН Е.Н. Носов; Предисловие составителей - д.и.н. А.Е. Мусин, к.и.н. М. В. Медведева; Введение и история архива д.и.н. А.Е. Мусин, к.и.н. М .В. Медведева, д.и.н. Г.В. Длужневская, Н. А. Белова; Летопись ИАК д.и.н. А.Е. Мусин; Глава I - д.и.н. А.Е. Мусин, к.и.н. М. В. Медведева, д.и.н. Н. И. Платонова, Л. М. Всевиов, д.и.н. И. Л. Тихонов; Глава II - д.и.н. Ю. А. Виноградов; Глава III - к.и.н. М. Ю. Вахтина; Глава IV д.и.н. Ю.А. Виноградов, д.и.н. А.Е. Мусин; Глава V - к.и.н. Р.В. Стоянов; Глава VI - д.и.н. Н.И. Платонова, д.и.н. А.Е. Мусин, д.и.н. С. А. Васильев; Глава VII - д.и.н. Г. В. Длужневская, Н. А. Лазаревская; Глава VIII к.и.н. О. В. Игнатьева-Вильбоа, д.и.н. Н. Б. Крыласова, д.и.н. А. М. Белавин; Глава IX - к.и.н. М.Б. Рысин,

В.Я. Стеганцева; Глава X - д.и.н. Г. В. Длужневская, д.и.н. Л. Б. Кирчо; Глава XI - д.и.н. А.Е. Мусин,

д.и.н. Г.В. Длужневская, к.и.н. М.В. Медведева, д.и.н. Н.И. Платонова; Глава XII - к.и.н. Д.Д. Ёлшин; Глава XIII - д.и.н. А.Е. Мусин, к.и.н. М.В. Медведева; Глава XIV - д.и.н. А. Е. Мусин, д.и.н. Н.И. Платонова; Биографии - д.и.н. И. Л. Тихонов, д.и.н. А.Е. Мусин; Библиография - Л. М. Всевиов; Английское резюме -

А. В. Гилевич; Указатели - д.и.н. А. Е. Мусин; Подготовка иллюстративного материала - Т. А. Ершова

В оформлении обложки использованы материалы ФО НА ИИМК РАН

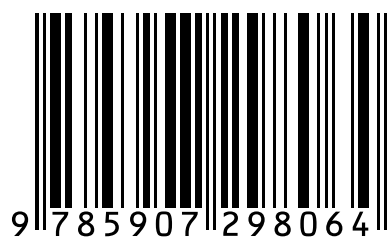




\section{СОДЕРЖАНИЕ}

\section{Том 1}

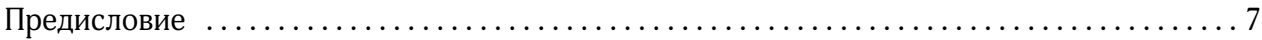

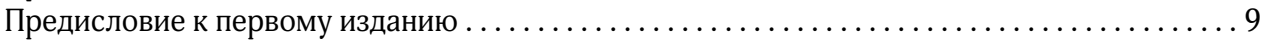

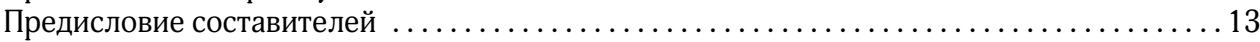

Введение. История формирования архива Императорской археологической комиссии и обзор ее фондов в Научном архиве Института истории

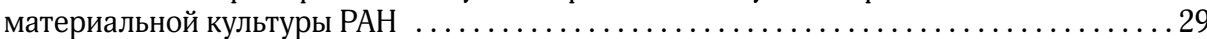

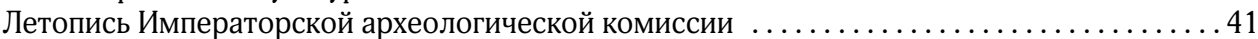

Сотрудники Императорской / Российской археологической комиссии, 1859-1918 . ...56

ГЛАВА І. Очерк истории деятельности Императорской археологической комиссии в $1859-1917$ гг. ......................................... 62

ГЛАВА II. Императорская археологическая комиссия и изучение древностей

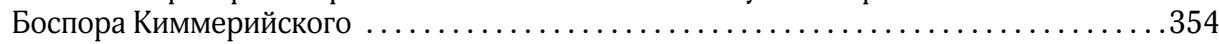

ГЛАВА ІІІ. Императорская археологическая комиссия и изучение

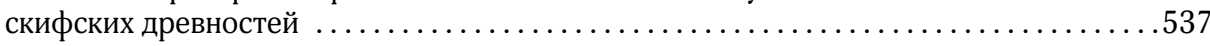

ГЛАВA IV. Императорская археологическая комиссия и исследование

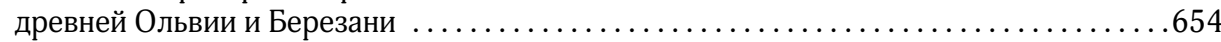

ГЛАВА V. Императорская археологическая комиссия и изучение

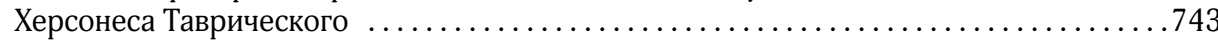

ГЛАВА VI. Императорская археологическая комиссия и первобытные древности . . . ..783

ГЛАВА VII. Археологические памятники Сибири в исследованиях Императорской

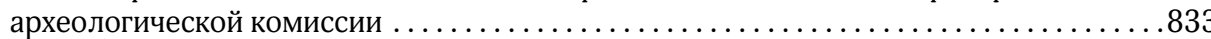

\section{Tом 2}

ГЛАВА VIII. Императорская археологическая комиссия

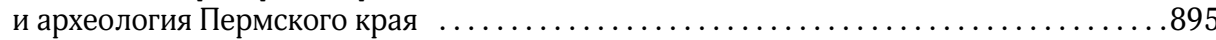

ГЛАВА ІХ. Императорская археологическая комиссия и исследование памятников Кавказа и Предкавказья . ................................. 921

ГЛАВА Х. Императорская археологическая комиссия и изучение древностей Средней Азии . . . . . . . . . . . . . . . . . . . . . . . . . . 1056

ГЛАВА ХІ. Славяно-русские и средневековые древности в исследованиях

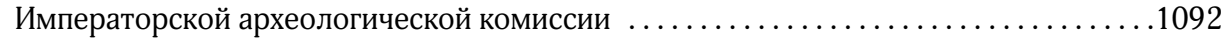

ГЛАВА XII. Императорская археологическая комиссия и раскопки

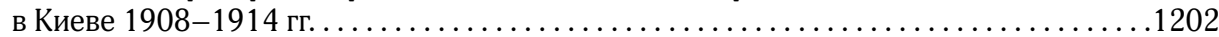

ГЛАВА XIII. Императорская археологическая комиссия: реставрация

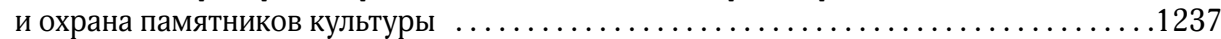

ГЛАВА XIV. Императорская археологическая комиссия и ее преобразование

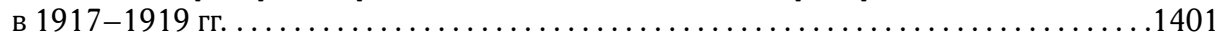

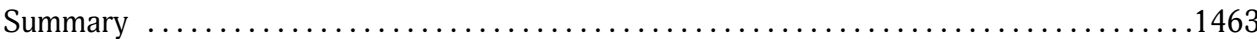

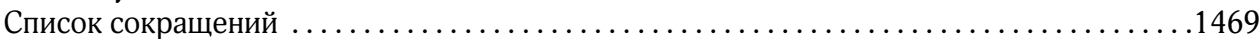

Библиография изданий Императорской / Российской археологической комиссии . . . 1476

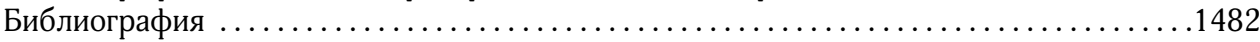

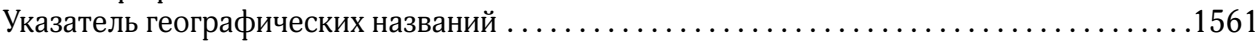

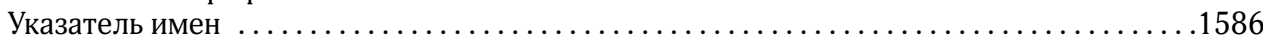

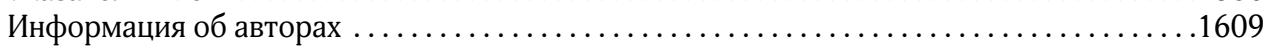




\section{CONTENTS}

\section{Volume 1}

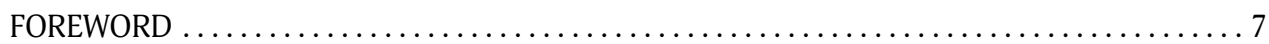

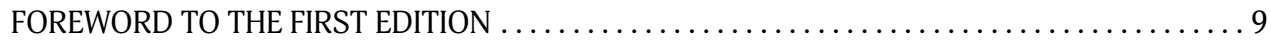

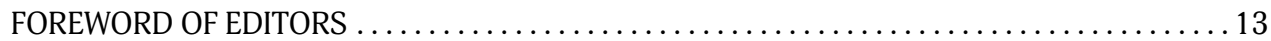

INTRODUCTION. The history of archives of the Imperial Archaeological Commission and surveys of its collection in the depository of the Institute for the History of the Material Culture, Saint Petersburg . . . . . . . . . . 29

Chronicles of the Imperial Archaeological Commission ......................... 41

Staff of the Imperial / Russian Archaeological Commission, 1859-1918 . . . . . . . . . . . . 56

CHAPTER I. Essay on the history of the Imperial Archaeological

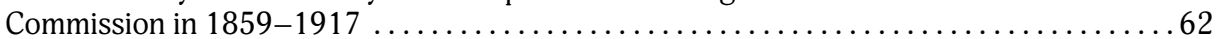

CHAPTER II. The Imperial Archaeological Commission and archaeology

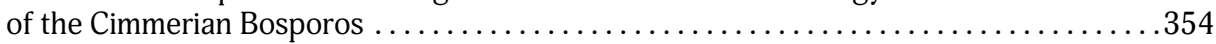

CHAPTER III. The Imperial Archaeological Commission and Scythian archaeology .........537

CHAPTER IV. The Imperial Archaeological Commission and archaeology of ancient Greek cities of Olbia and Berezan Island ........................ 654

CHAPTER V. The Imperial Archaeological Commission and archaeology of the Tauric Chersonesos . ...................................... 743

CHAPTER VI. The Imperial Archaeological Commission and prehistoric archaeology .......783

CHAPTER VII. The Imperial Archaeological Commission and archaeology of Siberia .......833

\section{Volume 2}

CHAPTER VIII. The Imperial Archaeological Commission and archaeology of the historical region of Perm

CHAPTER IX. The Imperial Archaeological Commission and archaeology of the Caucasus and Ciscaucasia

CHAPTER X. The Imperial Archaeological Commission and archaeology

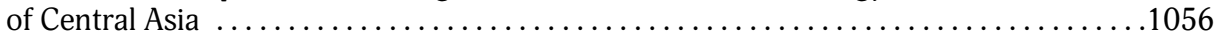

CHAPTER XI. The Imperial Archaeological Commission and Slavic

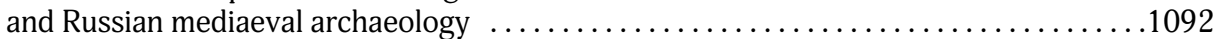

CHAPTER XII. The Imperial Archaeological Commission and excavations

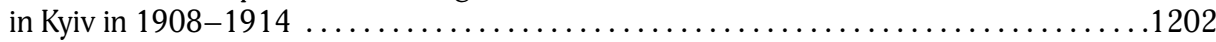

CHAPTER XIII. The Imperial Archaeological Commission: restoration

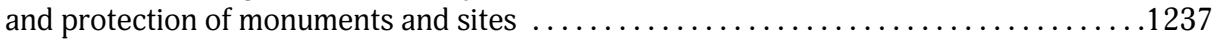

CHAPTER XIV. The Imperial Archaeological Commission and its reform

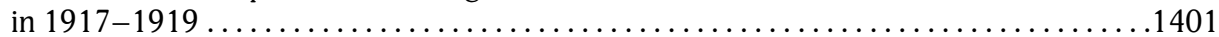

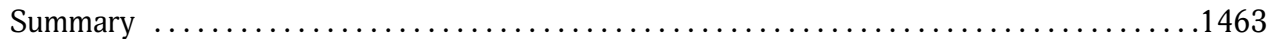

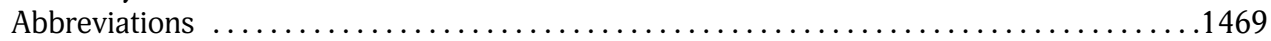

Bibliography of the publications of the Imperial / Russian Archaeological Commission ....1476

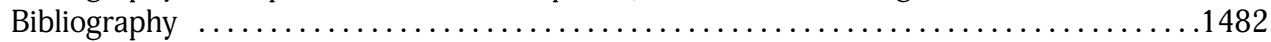

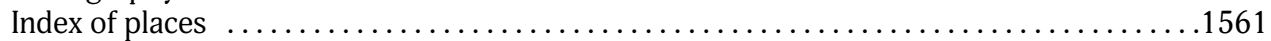

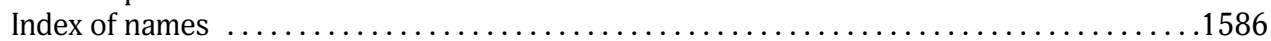

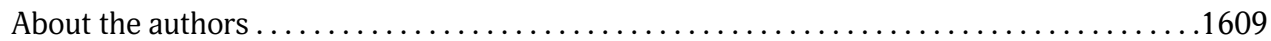


DOI: 10.31600/978-5-9072-9806-4-2019-41-55

\section{ЛЕТОПИСЬ \\ ИМПЕРАТОРСКОЙ АРХЕОЛОГИЧЕСКОЙ КОМИССИИ}

1859

2 февраля. Высочайшее утверждение Положения об ИАК

9 февраля. Назначение С.Г. Строганова председателем ИАК

26 февраля. Назначение П. С. Савельева старшим членом ИАК

26 февраля. Назначение А.С. Линевича производителем дел ИАК

26 февраля. Перевод в ИАК директора Керченского музея А.Е. Люценко

26 февраля. Перевод в ИАК помощника директора Керченского музея К.Р. Бегичева

3 апреля. Определение И.Н. Медведева художником ИАК

19 мая. Кончина старшего члена ИАК П.С. Савельева

9 июня. Назначение И.Е. Забелина младшим членом ИАК

Июль-сентябрь. Раскопки курганов Близницы в Екатеринославской губернии И.Е. Забелиным

1 ноября. Попытка получить для ИАК новое помещение вне Строгановского дворца

4 декабря. Доклад академика Ф.Г. Солнцева императору о состоянии средневековой стенописи и архитектуры во Владимире

20 декабря. Особое Высочайшее повеление об отнесении к обязанностям ИАК отыскания и возобновления древней стенной иконной живописи в старинных православных храмах; причисление к ИАК Ф.Г. Солнцева и П.И. Вольского

\section{0}

2 марта. Избрание Л.Э. Стефани членом-корреспондентом ИАК

Июнь. Исследование курганов на Белом озере в Новгородской губернии Я.М. Лазаревским и Ю.Б. Иверсеном

\section{1}

1 апреля. Определение Н. Д. Иванова канцелярским служащим ИАК

4 апреля. Назначение С. А. Гедеонова заведующим Римской археологической комиссией

23 ноября. Кончина делопроизводителя ИАК А.С. Линевича

21 декабря. Определение В.Г. Тизенгаузена делопроизводителем ИАК

\section{2}

1 февраля. Именной указ «О продолжении существования Императорской археологической комиссии и Керченского музея древностей» «на прежнем основании»

7 марта. Кончина помощника директора Керченского музея К. Р. Бегичева 
1 сентября. Назначение Ф.И. Гросса помощником директора Керченского музея

19 ноября. Письмо С.Г. Строганова в Главное управление путей сообщений и публичных зданий и в Инженерный департамент о доставлении в ИАК сведений о направлении проводимых дорог, производстве работ и сделанных находках

29 ноября. Письмо С.Г. Строганова в Центральный статистический комитет МВД с предложением о сотрудничестве в деле изучения и сохранения памятников старины

\section{3}

27 апреля. Циркуляр МВД по губернским статистическим комитетам «О доставлении сведений о памятниках древностей российских, к отечественной истории и жизни народов относящихся», рассылка «Программы археологических исследований, по которым ожидается содействие Статистических комитетов», составленной ИАК

9 июня. Назначение И.Е. Забелина старшим членом ИАК. Назначение С.А. Гедеонова директором Императорского Эрмитажа

Июль-август. Открытие И.Е. Забелиным скифского царского погребения в кургане Чертомлык

\section{4}

31 марта. Назначение В.Г. Тизенгаузена младшим членом ИАК

8 сентября. Записка В.Г. Тизенгаузена о сохранении Царского кургана в Керчи

14 сентября. Кончина сторожа ИАК А. Афанасьева
31 декабря. Увольнение канцелярского служащего ИАК Н. Д. Иванова

Начало раскопок В.Г. Тизенгаузена на Нижнем Дону

\section{5}

29 января. Отношение ИАК в Департамент железных дорог с просьбой уведомлять Комиссию о производстве работ в местах расположения курганов и городищ и о сдаче в Комиссию археологических находок

Экспедиция П.И. Лерха в Олонецкую, Вологодскую и Вятскую губернии для разыскания первобытных древностей

Раскопки В.В. Радловым Большого Катандинского кургана

\section{6}

1 января. Назначение И. А. Суслова журналистом ИАК

Апрель. «Приватное принятие» в ИАК Ф. Ланга для составления археологической библиографии

4 ноября. Циркуляр МВД о воспрещении кладоискательства и о доставлении по просьбе ИАК сведений о древних зданиях и находимых древностях вообще в Департамент общих дел

Издание первого выпуска «Материалов по археологии России»

Новочеркасский клад

\section{7}

7 января. Письмо С.Г. Строганова Г. А. Кушелеву-Безбородбко о выработке условий для проведения археологических розысканий в Ольвии

Определение У. Михайлова сторожем ИАК

Первый Гнездовский клад 


\section{8}

9 сентября. Кончина П.И. Вольского

29 ноября. Определение М.П. Клодта фон Юргенсбурга на место П.И. Вольского

\section{9}

Январь. «Приватное принятие» в ИАК Э. Боннеля для составления библиографии

11 ноября. Циркуляр МВД губернаторам о доставлении в Техническостроительный комитет подробного описания и чертежей памятников, крепостей и других зданий древности с объяснением прочности и мер, предпринимаемых местным начальством к сохранению и исправному содержанию этих зданий, с напоминанием, что по действующему Уставу строительному, т. XII Свода законов (по продолжению 1868 г.), ст. 181, 182, эти остатки строжайше воспрещено разрушать

\section{0}

17 апреля. Назначение А.В. Адлерберга министром императорского двора и уделов

\section{3}

2 марта. Определение П.И. Лерха делопроизводителем ИАК

1 мая. Увольнение М.П. Клодта фон Юргенсбурга

Договор между ИАК и владельцами земли с. Парутино (Ольвия) на 5 лет о ведении археологических работ. Начало раскопок И.Е. Забелина и В.Г. Тизенгаузена в Ольвии
1874

14 февраля. Заключение великого кн. Владимира Александровича по проекту наиболее действенных мер для охранения отечественных памятников

\section{5}

Июль-август. Начало раскопок В.Г. Тизенгаузеном Семибратних курганов

\section{6}

26 мая. Создание «Комиссии для обсуждения мер к охранению памятников древности» под председателем А.Б. Лобанова-Ростовского

3 июня. Увольнение И.Е. Забелина

17 июня. Назначение Н.П. Кондакова младшим членом ИАК

26 июля. Назначение В. Г. Тизенгаузена старшим членом ИАК

\section{7}

3 февраля. Назначение И.А. Суслова исполняющим обязанности делопроизводителя ИАК

\section{8}

1 января. Назначение И.Д. Деля младшим членом ИАК

1 января. Увольнение П.И. Лерха от должности делопроизводителя ИАК, определение И. А. Суслова делопроизводителем ИАК

1 апреля. Увольнение А.Е. Люценко от должности директора Керченского музея

1 апреля. Назначение С.И. Веребрюсова директором Керченского музея

15 сентября. Кончина С.А. Гедеонова 


\section{9}

24 октября. Кончина И. Д. Деля

\section{1}

17 августа. Назначение И.И. Воронцова-Дашкова министром императорского двора и уделов

\section{2}

17 января. Реформа Министерства императорского двора и уделов

7 марта. Увольнение С.Г. Строганова от должности председателя ИАК, назначение председателем ИАК А.А. Васильчикова

27 марта. Кончина С. Г. Строганова

20 октября. Представление А. А. Васильчиковым министру императорского двора проектов «Об изменении устава и штата ИАК» и положения об ИАК с поручением ей охраны исторических памятников в России

\section{3}

18 января. Ходатайство А.А. Васильчикова о дозволении г. Шлиману археологических исследований на Кавказе

11 февраля. Определение И.С. Сутулло на канцелярскую службу в ИАК по вольному найму

19 февраля. Высочайшее постановление об охране и сбережении памятников древности в Финляндии

Черниговский клад

\section{4}

6 марта. Кончина директора Керченского музея С.И. Веребрюсова
8 марта. Назначение Ф.И. Гросса директором Керченского музея

19 июня. Учреждение Археологической комиссии для заведования памятниками древности в Финляндии

5 июля -26 июля. Предписание Святейшего Синода епархиальным архиереям об обязательности сношений с ИАК в вопросе реставрации монументальных памятников церковной старины

4 сентября. Кончина П.И. Лерха

Начало раскопок Н.Н. Пантусовым несторианских средневековых кладбищ в Семиреченской области

\section{5}

Март-июль. Раскопки Н.И. Веселовского на Афрасиабе

4 мая. Начало работы Н.П. Кондакова над русско-византийскими кладами

\section{6}

12 января. Высочайшее повеление ИАК об издании русско-византийских кладов

1 февраля. Увольнение А.А. Васильчикова от должности председателя ИАК, назначение председателем ИАК А. А. Бобринского

11 марта. Кончина художника ИАК И.Н. Медведева

3 мая. Начало исследования Н.Е. Бранденбургом памятников Старой Ладоги при поддержке ИАК

7 мая. Памятная записка В.Г. Тизенгаузена о деятельности и заслугах ИАК в 1859-1886 гг.

16 мая. Докладная записка В.Г. Тизенгаузена о кандидатурах для избрания в почетные члены и члены-корреспонденты ИАК 
31 мая. Утверждение избрания Л.Э. Стефани и И.Е. Забелина почетными членами ИАК

8 июня. Записка И.И. Толстого об утилизации монетных кладов, поступающих в ИАК

22 августа. Утверждение избрания В. В. Стасова, В. В. Радлова, Ю.Б. Иверсена и Д.Я. Самоквасова членами-корреспондентами ИАК

1 сентября. Назначение И.И. Толстого младшим членом ИАК

26 сентября. Циркуляр ИАК епископату Греко-Российской Православной церкви о содействии духовных властей в противодействии кладоискательству на церковных землях и в сохранении отечественных древностей от уничтожения

20 ноября. Поручение Министерства императорского двора Иператорской археологической комиссии принять меры к сохранению Георгиевского собора в Юрьеве-Польском, Спасского собора в Мирожском монастыре в Пскове и двух часовен близ Переславля-Залесского, перечисленных в записке И. Ф. Барщевского

26 ноября. Циркуляр МВД гражданским губернаторам о «воспрещении кому бы то ни было предпринимать какие-либо археологические раскопки на казенных, церковных или общественных землях» без специального разрешения на то ИАК

28 ноября. Утверждение избрания Н.И. Веселовского членом-корреспондентом ИАК

1 декабря. Циркуляр ИАК епископату Римско-Католической церкви о содействии духовных властей в противодействии кладоискательству на церковных землях и в сохранении отечественных древностей от уничтожения

\section{7}

11 января. Циркуляр СанктПетербургского археологического института губернским архивным комиссиям о необходимости присылки случайных археологических находок в ИАК

21 января. Докладная записка председателя и членов ИАК в Императорскую академию художеств и Министерство императорского двора и уделов о необходимости юридического уточнения полномочий ИАК

4 марта. Мнение А.А. Бобринского по поводу предложения Археологического института о контроле со стороны губернских ученых архивных комиссий за продажей на публичных торгах древностей, принадлежащих частным лицам

8 марта. Докладная записка министра народного просвещения И.Д. Делянова в Комитет министров «По вопросу о мерах к охранению памятников старины от истребления, порчи и самовольных переделок»

Апрель. Начало осуществления программы систематического археологического исследования Киевского Полесья В.Б. Антоновичем

23 мая. Докладная записка Н.М. Ядринцева о состоянии археологических исследований и музейного дела в Сибири

12 июня. Высочайшее повеление об археологических исследованиях Херсонеса под руководством ИАК

13 июня. Рапорт А. А. Бобринского министру императорского двора о выделении 600-700 руб. для составления полного библиографического указателя археологической литературы

5 июля. Циркуляр МВД губернаторам о составлении описей древностей 
при продаже с торгов имущества частных лиц и о доставлении их в губернские ученые архивные комиссии

27 ноября. Письмо А.А. Бобринского министру народного просвещения с просьбой подтвердить подведомственным ему организациям, ученым учреждениям и частным ученым обществам необходимость соблюдения узаконений, касающихся полномочий ИАК в области контроля над раскопками на землях казенных и общественных

28 ноября. Начало исследования Старо-Рязанского городища при участии ИАК

Начало исследования Дрогичина Надбужского Н. П. Авенариусом

\section{8}

15 февраля. Утверждение И. А. Лопатина членом-корреспондентом ИАК

22 февраля. Письмо А.А. Бобринского министру народного просвещения об установлении общероссийского порядка в деле собирания и охранения древностей

18 апреля. Создание Комиссии по реставрации Георгиевского собора в Юрьеве-Польском, Спасского собора в Мирожском монастыре в Пскове и двух часовен близ Переславля-Залесского при участии ИАК

24 апреля. Утверждение новых штатов ИАК

1 мая. Определение И.С. Сутулло регистратором ИАК

Май. Начало систематических раскопок Херсонеса Таврического под общим руководством ИАК

8 декабря. Назначение М.П. Боткина сверхштатным членом ИАК

Открытие Мощинского клада в Калужской губернии Н.И. Булычевым
1889

11 марта. Высочайшее повеление об исключительном праве ИАК на производство и разрешение с археологической целью раскопок в империи на землях казенных, принадлежащих разным установлениям, и общественных, и о произведении реставрации монументальных памятников древности по предварительному соглашению с ИАК и по сношению ее с Императорской академией художеств

17-24 апреля. Археологическая конференция в Санкт-Петербурге, посвященная выработке соглашения ИАК с учеными обществами в области осуществления Высочайшего повеления от 11 марта

16 июня. Назначение В.Г. Дружинина членом ИАК без содержания для исполнения обязанностей ученого секретаря

28 июня. Высочайшее поручение члену ИАК Н.П. Кондакову составить описи древностей в монастырях и церквах на Кавказе и произвести их оценку

10 декабря. Назначение А. А. Бобринского вице-президентом Академии художеств

15 декабря. Совещание о соглашении ИАК с Эрмитажем и Историческим музеем по вопросу передачи древностей

\section{0}

16 марта. Передача метрик со сведениями о православных храмах из Императорской академии художеств в ИАК

27 апреля. Завершение переезда ИАК в новые помещения в Зимнем дворце

11 мая. Кончина А. А. Васильчикова

Экспедиция В. А. Жуковского в Мерв 
1 сентября. Определение И.Ф. Чистякова сторожем ИАК

31 октября. Утверждение «Правил о порядке рассмотрения Археологической комиссией и Академией художеств ходатайств о восстановлении древних монументальных памятников» министром императорского двора

20 декабря. Отставка А. А. Бобринского с поста вице-президента Академии художеств

Исследование Люцинского могильника Е.Р. Романовым

\section{1}

5 января. Увольнение И.И. Толстого от должности члена ИАК

15 января. Назначение В.Г. Дружинина членом ИАК

21 января. Увольнение Н.П. Кондакова от должности члена ИАК

11 февраля. Перевод Д.Я. Самоквасова из члена-корреспондента ИАК в ее сверхштатного члена

31 марта. Увольнение Ф.И. Гросса от должности директора Керченского музея, назначение К. Е. Думберга

4 мая. Циркуляр МВД губернаторам о точном и непременном соблюдении Высочайшего повеления от 11 марта 1889 г. в связи с тем, что «некоторые сельские общества составляют приговоры о дозволении частным лицам производить по своему усмотрению раскопки на общественных землях, чем наносится вред исследованию и сохранению древностей»

18 мая. Приказ по Ведомству путей сообщения о содействии ИАК в деле разыскания и охранения памятников отечественной старины, о сообщении сведений о направлениях проводимых дорог и о включении в контракты на подряды по земляным работам положения о сохранении и доставлении в ИАК всех остатков древности

1 июля. Принятие дел Керченского музея К. Е. Думбергом

\section{2}

8 января. Определение М. Викторова сторожем ИАК

1 февраля. Назначение В.Б. Антоновича и Н.И. Веселовского сверхштатными членами ИАК

3 марта. Кончина Ф.Г. Солнцева

23 марта. Назначение А. А. Спицына членом ИАК

26 мая. Введение нагрудного знака «Надсмотрщик Керченского музея» и приказ по Кабинету его императорского величества об обязательном составлении акта полицейскими чинами о производстве незаконных раскопок в присутствии служащих Комиссии

28 июля. Утверждение избрания В.В. Латышева членом-корреспондентом ИАК

Начало раскопок Н. Я. Марра в Ани

12 ноября. Предложение А.А. Бобринского МВД проводить земляные работы в Керчи в присутствии представителя Керченского музея и об усилении полицейского надзора и уголовной и гражданской ответственности за кладоискательство

11 декабря. Назначение Н.В. Покровского сверхштатным членом ИАК

\section{3}

11 апреля. Вторичное подтверждение Высочайшей воли о полномочиях ИАК в области реставрации монументальных памятников зодчества

26 апреля. Принятие Н.И. Суслова на канцелярскую службу в ИАК по вольному найму 
10 мая. Высочайшее посещение раскопок в Херсонесе императором Александром III

26 мая. Избрание А. Л. Бертье-Делагарда и А.С. Лаппо-Данилевского членами-корреспондентами ИАК

15 октября. Включение Высочайшего повеления от 11 марта 1889 г. во временный устав Императорской академии художеств

Начало реставрации Софийского собора в Новгороде

\section{4}

23 мая. Избрание Ю. А. Кулаковского и Н.Н. Пантусова членами-корреспондентами ИАК

25 августа. Предписание Кабинета е. и. в. частным ученым обществам о дозволении проведения раскопок на «Высочайше дарованные средства» только при разрешении ИАК

10 ноября. Циркулярное подтверждение МВД по губерниям о доставлении всех случайных археологических и нумизматических находок в ИАК

16 ноября. Определение Святейшего Синода о точном исполнении Высочайшего повеления от 11 марта 1889 г. касательно реставрации монументальных памятников древности

22 декабря. Поручение ИАК А.И. Шляпкину исследований граффити Софийского собора и памятников новгородской эпиграфики

29 декабря. Назначение В.Г. Тизенгаузена товарищем председателя ИАК

Начало реставрации Бахчисарайского дворца в Крыму

\section{5}

1 января. Назначение Н.И. Веселовского старшим членом ИАК
6 января. Избрание В.А. Жуковского, И.С. Китнера и Г.И. Котова членамикорреспондентами ИАК

20 февраля. Избрание В.К. Мальмберга членом-корреспондентом ИАК

20 ноября. Учреждение нагрудного знака «Надсмотрщик ИАК», надеваемого при отправлении служебных обязанностей

\section{6}

20 февраля. Письмо А. А. Бобринского епископату Греко-Российской Православной церкви с просьбой о доставлении в ИАК изданных описаний церквей и монастырей

10 апреля. Предложение А. А. Бобринского в МВД о введении в инструкции урядникам статьи о наблюдении за раскопками и доставлении в ИАК найденных древностей

12 ноября. Кончина Ф.И. Гросса.

22 ноября. Увольнение В.Г. Дружинина от должности члена ИАК

27 ноября. Утверждение А. А. Бобринским «Положения о распределении обязанностей служащих ИАК»

1 декабря. Назначение Ф. А. Брауна членом ИАК

Открытие склепа Деметры в Керчи

Раскопки Н.Н. Новокрещенных Гляденовского костища в Пермской губернии

\section{7}

20 марта. Назначение Н.В. Султанова сверхштатным членом ИАК

6 мая. Назначение В.Б. Фредерикса министром императорского двора и уделов

Раскопки Н.И. Веселовским Майкопского кургана

Начало проекта по изданию памятников древнерусской эпиграфики 


\section{8}

4 марта. Предложение А.А. Бобринского о создании при губернских статистических комитетах отделений по учету памятников древности

7 марта. Избрание К. К. КосцюшкоВалюжинича членом-корреспондентом ИАК

27 марта. Утверждение избрания А.Е. Комаровского сверхштатным членом ИАК

26 апреля. Определение Н.И. Суслова канцелярским служителем ИАК

20 июля. Определение Н.В. Суходольского на канцелярскую службу в ИАК по вольному найму

22 августа. Посещение раскопок Херсонеса Таврического императором Николаем II

\section{9}

14 августа. Кончина А.Е. Комаровского

Осмотр Н.В. Султановым Псковских крепостных стен

\section{0}

26 февраля. Определение А.С. Раевского на службу в ИАК

13 апреля. Кончина Ю. Б. Иверсена

27 мая. Увольнение В.Г. Тизенгаузена от должности товарища председателя ИАК

27 мая. Высочайшее повеление о возложении на ИАК систематических раскопок в Ольвии

29 июня. Назначение В. В. Латышева товарищем председателя ИАК

16 декабря. Увольнение Ф.А. Брауна от должности члена ИАК и назначение его сверхштатным членом ИАК

Издание новой редакции Строительного устава, учитывающей Высочайшее повеление от 11 марта 1889 г. о реставрации монументальных памятников

Начало работ С.И. Сергеева в Гнездово

\section{1}

1 января. Определение Д. Павлова сторожем ИАК

1 марта. Назначение Б.В. Фармаковского членом ИАК

2 июля. Начало систематических раскопок Б.В. Фармаковского в Ольвии

15 июля. Увольнение К. Е. Думберга из Керченского музея

16 июля. Принятие дел Керченского музея В.В. Шкорпилом

6 сентября. Циркуляр МВД губернаторам, градоначальникам и оберполицмейстерам о представлении в министерство списков памятников старины

Начало издания «Известий Императорской археологической комиссии»

\section{2}

5 января. Назначение В.В. Шкорпила директором Керченского музея

12 января. Определение А.С. Раевского делопроизводителем ИАК

18 января. Избрание С. А. Жебелева членом-корреспондентом ИАК

2 февраля. Кончина В.Г. Тизенгаузена

Сентябрь. Посещение императором Николаем II раскопок Херсонеса

2 ноября. Увольнение И. А. Суслова ИАК

6 декабря. Введение новых штатов

6 декабря. Определение Н.В. Суходольского чиновником XII класса канцелярским служащим ИАК

16 декабря. Назначение П.П. Покрышкина членом ИАК 


\section{3}

1 января. Определение Н.И. Суслова чиновником XII класса - канцелярским служащим ИАК

18 февраля. Избрание Э. А. Реслера членом-корреспондентом ИАК

22 марта. Назначение Н.И. Булычева сверхштатным членом ИАК

23 ноября. Замечания А.А. Бобринского по поводу предполагаемой реформы архивного дела в России, направленные им в канцелярию Министерства императорского двора и уделов

Реставрация фресок в костеле св. Троицы Люблинского замка

\section{4}

9 апреля. Посещение императором Николаем II Археологической комиссии

30 апреля. Предложение МВД духовным установлениям иностранных исповеданий о соблюдении повеления 1889 г. в части реставрации культовых зданий

Апрель-май. Командировка в Грецию В.В. Шкорпила

Июнь-сентябрь. Раскопки Н.И. Веселовским Келермесских курганов

Декабрь. Образование Особой комиссии МВД по пересмотру действующих постановлений об охранении древних памятников и зданий

Раскопки могильника Суук-Су в Крыму

\section{5}

10 июня. Назначение Б.И. Ханенко сверхштатным членом ИАК

Открытие А. А. Спицыным палеолитической стоянки у села Борщево

Публикация первого выпуска «Мечетей Самарканда»
1906

20-26 июня. Областной историкоархеологический съезд во Владимире

10 октября. Кончина В.В. Стасова

1907

12 апреля. Избрание А.К. Маркова и Н.Я. Марра членами-корреспондентами ИАК

16 декабря. Кончина заведующего раскопками в Херсонесе К. К. Косцюшко-Валюжинича

1908

1 апреля. Назначение Р.Х. Лепера членом ИАК и заведующим раскопками в Херсонесе

2 апреля. Высочайшее повеление ИАК об археологических исследованиях в Киеве

2 сентября. Кончина Н. В. Султанова

1909

4 февраля. Предложение А. А. Бобринского Государственной думе о распространении положений Высочайшего повеления от 11 марта 1889 г. на памятники археологии, находящиеся на крестьянских усадебных наделах

5 февраля. Празднование 50-летнего юбилея ИАК

20 апреля. Назначение Э.Р. фон Штерна сверхштатным членом ИАК

1 октября. Увольнение Н.И. Суслова и определение Д.В. Милеева чиновником XII класса - канцелярским служащим ИАК

15 ноября. Кончина И. А. Лопатина 


\section{0}

1 января. Определение А.С. Раевского на должность библиотекаря ИАК, И.С. Сутулло - делопроизводителем ИАК и Н.В. Суходольского - регистратором ИАК

18 мая. Определение Л.А. Филиппова чиновником XII класса - канцелярским служащим ИАК

14 июня. Принятие Государственной думой закона «Об изменении и дополнении некоторых постановлений о крестьянском владении» для проведения раскопок археологических памятников, находящихся на укрепленных в личную собственность крестьян участках, с соблюдением правил, установленных Высочайшим повелением от 11 марта 1889 г.

14 декабря. Избрание К. К. Романова членом-корреспондентом ИАК

Начало деятельности «полевой археологической школы» А.А. Спицына в Лужском уезде Санкт-Петербургской губернии

Осмотр П.П. Покрышкиным смоленских крепостных стен

Начало реставрации Успенского собора Московского Кремля

\section{1}

1 февраля. Празднование 25-летнего юбилея служения А.А. Бобринского председателем ИАК

1 марта. Увольнение Э.Р. Штерна из сверхштатных членов ИАК

7 марта. Назначение Ю. А. Кулаковского сверхштатным членом ИАК

12 июня. Начало исследования места находки Перещепинского клада

6 августа. Кончина Д.Я. Самоквасова
29 октября. Внесение в Государственную думу «Положения об охране древностей», выработанного Межведомственной комиссией

Начало реставрации Ипатьевского монастыря в Костроме

\section{2}

Август. Командировка А. А. Спицына в Стокгольм на Международный археологический конгресс

7 октября. Назначение А.А. Ширинского-Шихматова и М.И. Ростовцева сверхштатными членами ИАК

Укрепление колокольни Успенской церкви в Архангельске

\section{3}

Март. Поездка А.А. Бобринского, Б. В. Фармаковского, М.И. Ростовцева и Э.Р. Штерна в Лондон на Международный конгресс историков

Июль. Посещение императором Николаем II раскопок Херсонеса

1 августа. Высочайшее соизволение на учреждение под председательством великого князя Георгия Михайловича Особого совещания для выработки основ законопроекта о всероссийском национальном музее в память 300-летия царствования дома Романовых

Июль-август. Открытие Н.И. Веселовским царского захоронения в кургане Солоха

1 октября. Определение в ИАК Е.Н. Щербаковой для канцелярских занятий

25 ноября. Избрание членом-корреспондентом ИАК М.В. Фармаковского

21 декабря. Завершение работы Комиссии по приему коллекции Ф.М. Плюшкина при участии ИАК 


\section{4}

22 января. Кончина М. П. Боткина

19 июля. Кончина Д. В. Милеева

1 октября. Увольнение Р.Х. Лепера от должности члена ИАК

1 ноября. Определение К.И. Высотина чиновником XII класса - канцелярским служащим ИАК

\section{5}

29 января. Создание Комиссии Святейшего Синода по вопросу «устранения затруднений при перестройках и ремонтах церквей, имеющих археологическое значение» под председательством архиепископа Новгородского и Старорусского Арсения (Стадницкого)

20 июля. Указ Святейшего Синода о порядке разрешения споров между ИАК и духовными консисториями путем передачи дела в Синод

1 декабря. Рассылка статьи П.П. Покрышкина «Краткие сведения по вопросам ремонта памятников старины и искусства» в духовные консистории

14 декабря. Назначение Л. А. Моисеева членом ИАК и заведующим раскопками в Херсонесе

\section{6}

11 февраля. Увольнение Е.Н. Щербаковой

10 апреля. Присвоение А.А. Спицыну по ходатайству А.А. Бобринского «в виде исключения» чина действительного статского советника

20 мая. Кончина И.И. Толстого

16 августа. Письмо Канцелярии Святейшего Синода А.А. Бобринскому с разъяснением позиции Синода по поводу указа от 20 июля 1915 г. и с подтверждением его действенности
1917

8 февраля. Избрание А.И. Малеина членом-корреспондентом ИАК

6 марта. Постановление Археологической комиссии на своем экстренном заседании «всецело руководствоваться в своей дальнейшей деятельности распоряжениями Временного правительства»

8 марта. Кончина Н.В. Покровского

8 марта. Назначение Ф.А. Головина комиссаром над бывшим Министерством императорского двора и уделов

12 марта. Учреждение Союза деятелей искусств при участии ИАК

23 мая. Принятие положения о Российской археологической комиссии ее пленарным собранием

26 мая. Кончина Б. И. Ханенко

20 июня. Включение представителей РАК в Комиссию по приему и охране дворцовых имуществ Москвы при Городской думе

27 июня. Учреждение Кавказского историко-археологического института в Тифлисе

1 сентября. Приказ о вывозе из Петрограда ценностей, находящихся во дворцах Эрмитажа и других хранилищах бывшего Министерства двора

8 декабря. Приказ народного комиссара по просвещению и ведомству дворцов и музеев республики А.В. Луначарского о переезде РАК совместно с Археологическим институтом в бывшее здание Управления воздушным флотом

\section{8}

4 января. Кончина В. А. Жуковского 22 февраля. Утверждение Поместным собором Православной Российской церкви «Определения о епархиальном 
управлении», исключавшего РАК из порядка рассмотрения дел о реставрации памятников церковной старины и передававшего эти вопросы в ведение епархиальных архиереев

26 марта. Образование Хозяйственного комитета РАК

12 апреля. Кончина Н.И. Веселовского

9 мая. Утверждение избрания А. А. Спицына старшим членом РАК

12 мая. Кончина В.В. Радлова.

15 мая. Избрание А.П. Удаленкова исполняющим обязанности члена РАК, С.Н. Наседкина - временным сотрудником и В.Г. Самойлова - каталогизатором РАK

16 мая. Назначение Н.Я. Марра штатным членом РАК

1 июня. Увольнение К.И. Высотина

Июнь. Преобразование РАК в РГАК в ведении Народного комиссариата просвещения

1 июля. Избрание А.Д. Руднева и Н.А. Энман ассистентами РГАК, Е.О. Прушевской и К.В. Тревер - регистраторами научных коллекций РГАК

21 июля. Подписание А. А. Бобринским последних документов от имени РАК в Петрограде и его отъезд на юг России

1 август. Избрание Н.П. Удаленкова техником-чертежником РГАК

13 августа. Избрание Е.П. Столицы корректором РГАК

15 августа. Избрание Г.В. Стебницкого регистратором научных коллекций РГАК

1 сентября. Избрание С. Ф. Ольденбурга членом РГАК

3 сентября. Возвращение РГАК в Зимний дворец

24 сентября. Обсуждение проекта нового устройства Комиссии и избрание А.Л. Бертье-Делагарда,
Ф.А. Брауна, С.А. Жебелева, Г.И. Котова, Ю.А. Кулаковского, А.С. Лаппо-Данилевского, В.К. Мальмберга, А.К. Маркова, А.И. Малеина, М.И. Ростовцева, Э. Р. фон Штерна и М. В. Фармаковского членами Совета РГАК

1 октября. Принятие устава РГАК, избрание В.В. Бартольда, А.А. Ильина, С. Ф. Платонова, Н. П. Сычева и Б. А. Тураева членами Совета РГАК

4 октября. Кончина Р.Х. Лепера

17 октября. Утверждение устава РГАК А.В. Луначарским, избрание А.А. Васильева, В.К. Шилейко и Н.П. Остроумова членами РГАК и С. Г. Елисеева - ассистентом РГАК

22 октября. Избрание А. А. Миллера и К. К. Романова членами РГАК

13 ноября. Избрание Н.Я. Марра председателем РГАК

28 ноября. Первое заседание Библиотечного комитета РГАК

5 декабря. Избрание И.А. Орбели членом Совета РГАК и С.С. Лукьянова - ассистентом РГАК

26 декабря. Избрание Н.П. Сычева членом РГАК и А.А. Семенова - ассистентом РГАК

27 декабря. Убийство В.В. Шкорпила

\section{9}

3 января. Избрание В.Н. Крейтона, В.Е. Лавровского, А.Н. Малова и иеромонаха Иннокентия (Тихонова) научными сотрудниками РГАК

16 января. Избрание Н.Е. Макаренко членом Совета РГАК и А.И. Кудрявцева - ассистентом РГАК

23 января. Обращение председателя РГАК Н.Я. Марра к патриарху Тихону (Белавину) с призывом к сотрудничеству духовенства с Археологическим отделом при Всероссийской коллегии 
по делам музеев и охране памятников искусства и старины Народного Комиссариата просвещения

7 февраля. Кончина А.С. ЛаппоДанилевского

6 марта. Вступление коллектива служащих РГАК в Союз работников культурно-просветительских и учебно-воспитательных учреждений города Петрограда и его окрестностей

17 марта. Обсуждение на Совете РГАК проекта Положения о Российской Государственной академии археологических знаний

20 марта. Утверждение инструкций Библиотечного комитета для руководства объединенной библиотекой РГАК

2 апреля. Создание комитета младших служащих РГАК

18 апреля. Декрет о создании в Петрограде Российской Академии истории материальной культуры в системе Народного комиссариата просвещения на основе РГАК

27 мая. Оглашение Декрета о РАИМК на совете РГАК

31 мая. Решение Коллегии Народного комиссариата просвещения о предоставлении Мраморного дворца в распоряжение РАИМК

4 июня. Утверждение Коллегией Народного комиссариата просвещения инструкции по выбору членов РАИМК

21 июня. Чрезвычайное заседание Совета РГАК, начало реорганизации Комиссии

15 июля. Первые выборы членов РАИМК на заседании Совета РГАК

5-7 августа. Избирательное собрание РАИМК

7 августа. Прекращение работы РГАК - начало деятельности РАИМК

\section{6}

12 января. Утверждение Государственным Ученым советом Устава Государственной Академии истории материальной культуры

\section{7}

30 июня. Приказ народного комиссара просвещения о передаче ГАИМК и ее Московского отделения в ведение AH CCCP

5 августа. Преобразование Государственной Академии истории материальной культуры в Институт истории материальной культуры в системе Академии наук СССР, создание Московского отделения Института истории материальной культуры

5 октября. Постановление Президиума АН СССР об определении задач и утверждении структуры ИИМК

\section{3}

15-16 октября. Постановление Президиума АН СССР о руководстве ИИМК АН СССР, освобождение М.И. Артамонова от обязанностей директора и назначение академика Б. Д. Грекова и. о. директора Института; перевод дирекции Института истории материальной культуры из Ленинграда в Москву

\section{5}

9 февраля. Решение Президиума АН СССР о преобразовании Московского отделения ИИМК в основной Институт и о создании Ленинградского отделения ИИМК 
1959

4 сентября. Постановление Президиума АН СССР о переименовании Института истории материальной культуры в Институт археологии

\section{4}

Публикация в журнале «Советская археология» статьи К.М. Пескаревой и Е.А. Рябинина, посвященной 125-летИю ИАК

\section{1}

25 июня. Постановление Президиума АН СССР о преобразовании Ленинградского отделения Института археологии в Институт истории материальной культуры

А.Е. Мусин 